\title{
PREDICTION OF MECHANICAL STRENGTH OF POLYPROPYLENE FIBRE REINFORCED CONCRETE USING ARTIFICIAL NEURAL NETWORK
}

\section{PREDVIĐANJE MEHANIČKE ČVRSTOĆE BETONA OJAČANOG POLIPROPILENSKIM VLAKNIMA KORIŠĆENJEM VEŠTAČKE NEURONSKE MREŽE}

\author{
P. SANGEETHA \\ M. SHANMUGAPRIYA
}

ORIGINALNI NAUČNI RAD ORIGINAL SCIENTIFIC PAPER

UDK:624.971.012.45:004.032.26 doi:10.5937/GRMK2004079S

\section{INTRODUCTION}

The Polypropylene fibre reinforced concrete (PFRC) contains randomly distributed concrete and it acts as internal reinforcement so as to enhance the properties of the cementitious composite (concrete). The principal reason for incorporating the Polypropylene fibres into a cement matrix is to reduce cracking in the elastic range, and to increase the tensile strength and deformation capacity and increase the flexural strength of the resultant concrete. These properties of PFRC primarily depend upon the length and volume of propylene fibres (PPF) used in the concrete mixture. The strength properties of the concrete reinforced with polypropylene fibre and alkali resistant glass fibres was predicted by Regression modelling and found near to the experimental results of all the specimens [1]. The predicted compressive strength of concrete form the different batching plants for fresh concrete and early strength using artificial neural network [2]. The Intelligent Prediction system of concrete strength was developed, to provide strength information for removal of form work and scheduling the construction [3]. The split tensile strength and percentage of water absorption of concrete containing $\mathrm{TiO}_{2}$ nanoparticles were predicted by using ANN and genetic programming and also concluded that ANN prediction is better than genetic programming [4]. The application of the Artificial neural network for predicting drying shrinkage of concrete was performed and found that prediction was in good agreement with the experimental strength [5].

P. Sangeetha, Department of Civil Engineering, Sri Sivasubramaniya Nadar College of Engineering, Chennai, Tamilnadu, India, sangeethap@ssn.edu.in

M. Shanmugapriya, Department of Mathematics, Sri Sivasubramaniya Nadar College of Engineering, Chennai, Tamilnadu, India, shanmugapriyam@ssn.edu.in
The strength predictions of high performance steel fibre concrete with different volume of fibres were established using regression models and its second order regression model gives better predictions when compared to actual strength [6]. In the recent years an Artificial Neural Network (ANN) has been used to predict the behaviour of the mechanical properties of the concrete and various civil engineering structures. The compressive stress of the FRP confined and unconfined concrete column was predicted from the experimental and analytical results using ANN [7]. Previous studies [8-10] have developed the concrete compressive strength prediction model using ANN and Genetic Programming. This paper discusses the experimental study on the polypropylene fibre reinforced concrete to find the mechanical properties for different volume of fibre at 7 days and 28 days of curing. The prediction of strength using ANN approach was also discussed and compared.

\section{EXPERIMENTAL STUDY}

The ingredients of concrete were studied properly to identify its properties of the ingredients. Table 1 presents the properties of the polypropylene fibres. Concrete preparation was done by mixing constitute materials with different percentage of fibre thoroughly to avoid the segregation of fibres. Figure 1 shows the batching of ingredients of the polypropylene concrete. All the specimens casted with different proportion were cured under room temperature in the water tank. Figure 2 and 3 shows the cube, cylinder and prism specimens in order to find the compressive strength, split tensile strength and flexural strength of the specimen respectively. After 7 and 28 days of curing, the specimens were tested under compression testing machine of capacity $2000 \mathrm{kN}$ and universal testing machine of capacity $600 \mathrm{kN}$ to measure compressive strength, split tensile strength and flexural 
strength of the specimens respectively. Figure 4 shows the loading position of the specimens.

Table 1. Properties of Polypropylene fibre

\begin{tabular}{|c|c|c|c|c|c|c|}
\hline Fibre & $\begin{array}{c}\text { Tensile } \\
\text { Strength } \\
\text { (gf/den) }\end{array}$ & $\begin{array}{c}\text { Elongation } \\
(\%)\end{array}$ & $\begin{array}{c}\text { Relative } \\
\text { density }\end{array}$ & $\begin{array}{c}\mathrm{L} \\
(\mathrm{mm})\end{array}$ & $\begin{array}{c}\text { Aspect } \\
\text { Ratio }\end{array}$ \\
\hline Polypropylene & 4.5 & 60 & 0.91 & 12 & 0.03 & 400 \\
\hline
\end{tabular}

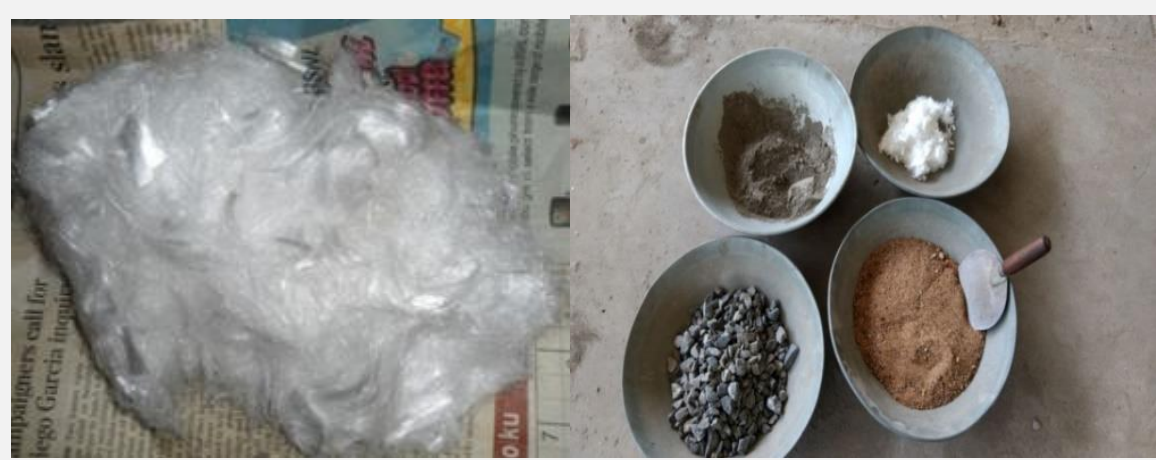

Figure 1. Polypropylene fibre and ingredients of concrete

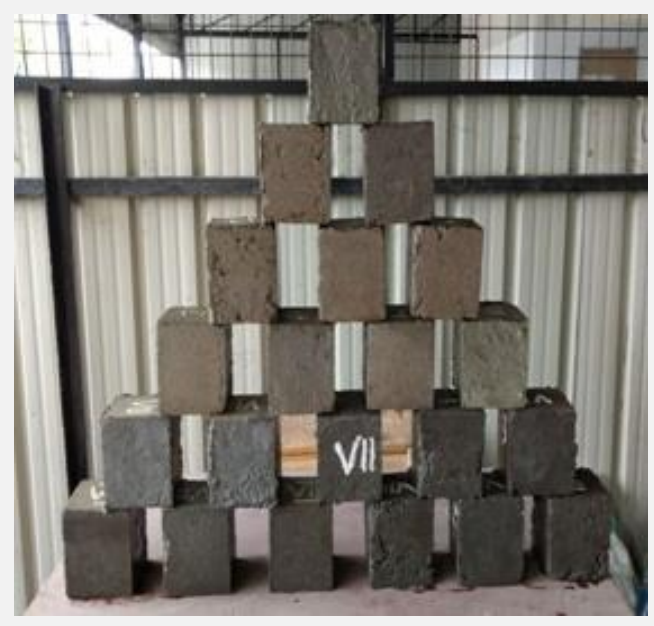

Figure 2. Test Specimens to measure compressive strength

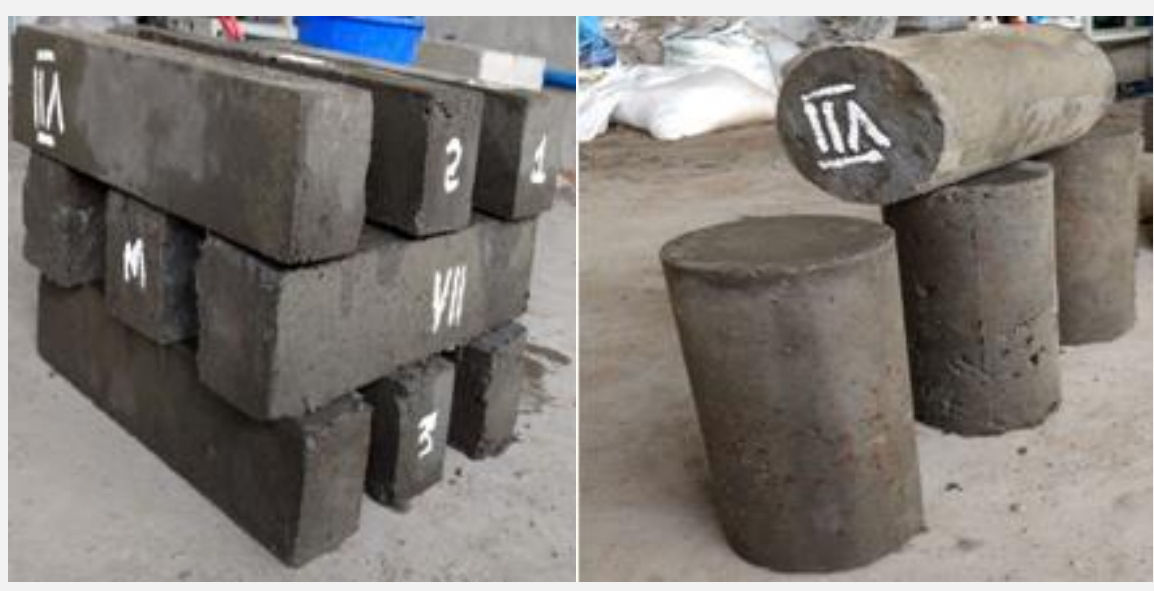

Figure 3. Test specimens to measure flexural and split tensile strength 


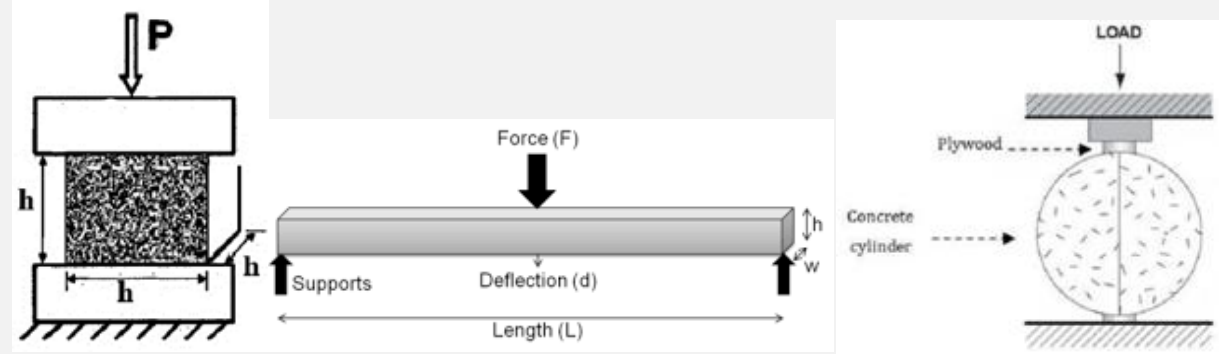

Figure 4. Test set up of the specimens

The increase in the percentage of fibres in the concrete increases the compressive strength, flexural strength and split tensile strength by $8 \%, 20 \%$ and $40 \%$ respectively for change in the percentage of fibre from 0.5 $\%$ to $2.0 \%$ by volume of cement. Figure 5 shows the comparison between the strength and \% of fibre content for two curing period 7 days and 28 days.

\section{ARTIFICIAL NEURAL NETWORK}

The ANN prediction model is performed using $M A T L A B$ with one hidden layer of twenty-five hidden

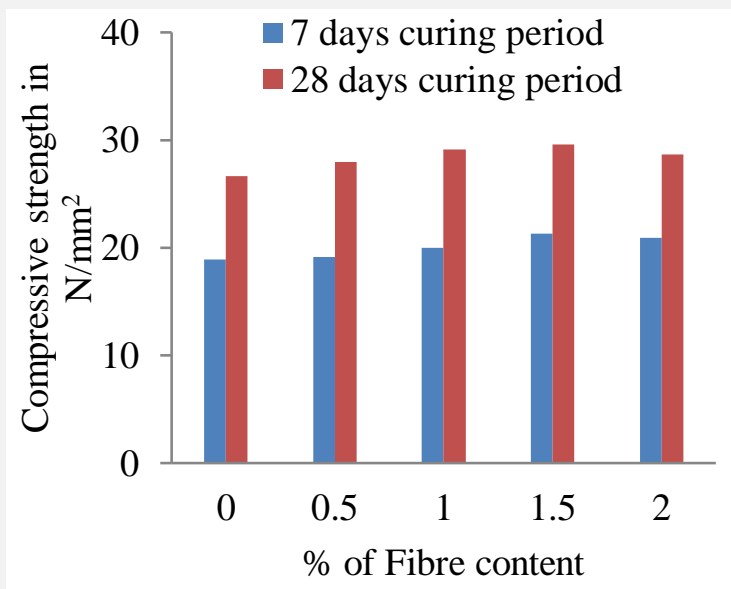

neurons and one output layer of dependent variables like compressive strength, flexural strength and split tensile strength. $70 \%, 15 \%$ and $15 \%$ of the date has been used for training, testing and validation respectively. The layered feed-forward networks have been used to predict the mechanical strength of concrete in LevenbergMarquardt algorithm. In this network the signals are sent forward and errors are propagated backwards. The performance of ANN model to predict the mechanical strength of the concrete was measured using some statistical methods. The tests involved are coefficient of determination $\left(R^{2}\right)$, Mean Squared Error (MSE), Mean Absolute Error (MAE) and Sum of Squared Errors (SSE).

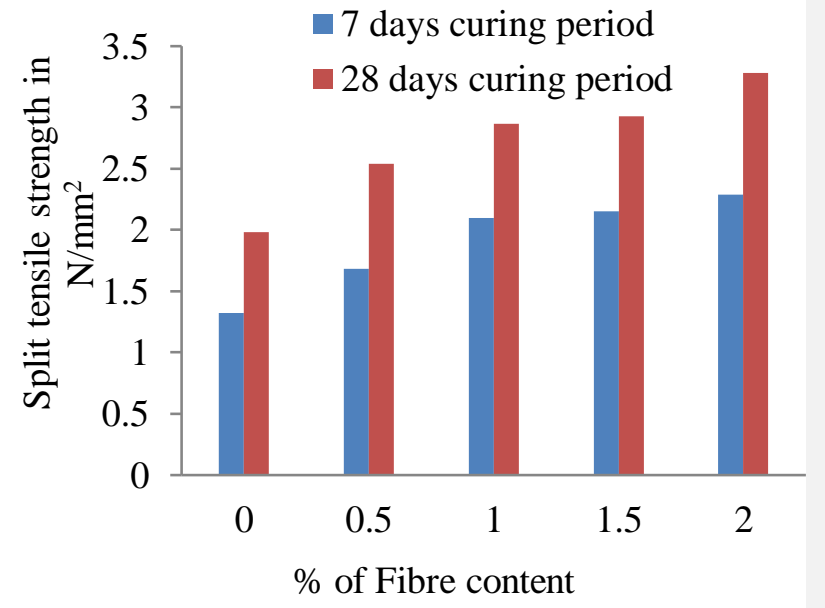

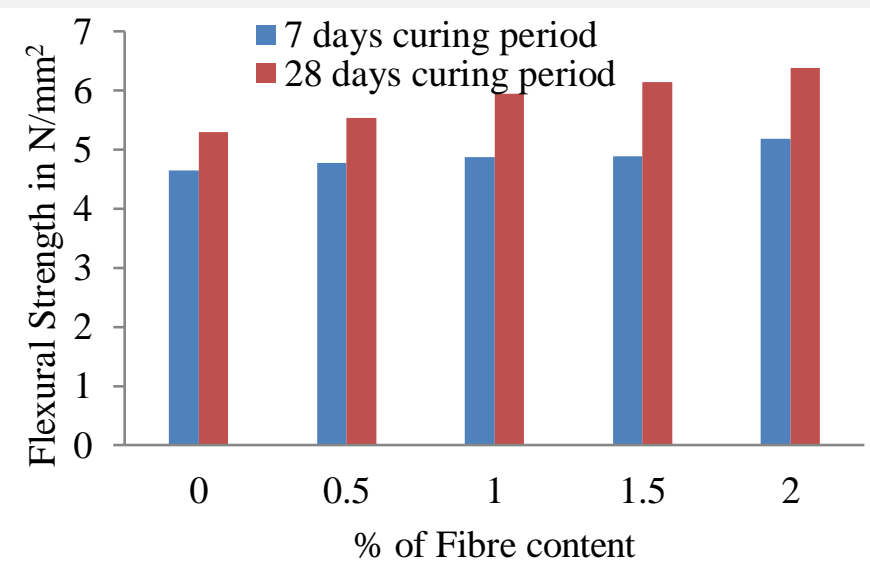

Figure 5. Effect of Polypropylene Fibre on the mechanical properties of concrete 


$$
\begin{gathered}
R^{2}=1-\frac{\sum_{i=1}^{N}\left(E_{i}-P_{i}\right)^{2}}{\sum_{i=1}^{N}\left(E_{i}-\bar{E}\right)^{2}} \\
M S E=\frac{1}{N} \sum_{i=1}^{N}\left(E_{i}-P_{i}\right)^{2} \\
M A E=\frac{1}{N} \sum_{i=1}^{N}\left|\left(E_{i}-P_{i}\right)\right| \\
S S E=\sum_{i=1}^{N}\left(E_{i}-P_{i}\right)^{2}
\end{gathered}
$$

where $E_{i}, P_{i}$ and $N$ denote the experimental value, predicted value and the number of data points, respectively.

Figure 6 demonstrates the test errors for compressive strength, flexural strength and split tensile strength of the polypropylene fibre reinforced concrete. The MSE, MAE and SSE values are obtained by varying the number of hidden neurons and found that the test errors attained minimum for 11 neurons in compressive strength, 23 neurons in flexural strength and 12 neurons in split tensile strength. The optimum hidden neurons are employed to predict the mechanical strength of fibre reinforced concrete with three different neural networks. In addition, the comparison of $\mathrm{R}^{2}$, MSE, MAE and SSE with the curing period days of 7 and 28 for all specimens is presented in table 2.

The experimental and predicted values for training, validation and testing obtained from MATLAB programme for compressive strength, flexural strength and split tensile strength are shown in figure 7 to 9 respectively. From figure 7 to 9 it is observed that the distribution of the network outputs verses the target values for all data sets are distributed along the optimal agreeable line. The correlation between the predicted and target components was found to be $(0.99785,0.99495,0.99865)$ for compressive strength, $(0.98618,0.98739,0.99944)$ for flexural strength and $(0.9959,0.99423,0.99595)$ for split tensile strength in the training, validation and testing process of the network and it is found to be satisfactory.
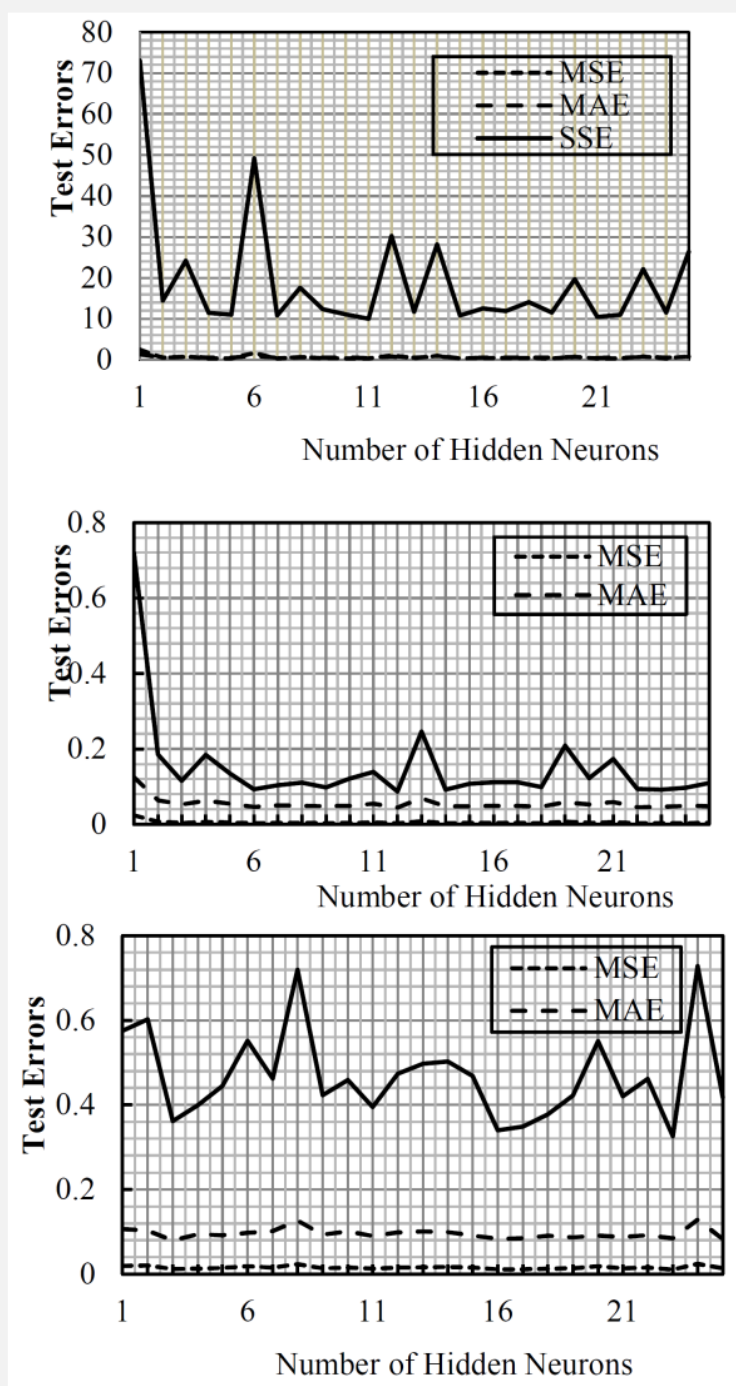

\begin{tabular}{|c|c|c|c|c|c|}
\hline Model & $\begin{array}{l}\text { Period of } \\
\text { Curing(days) }\end{array}$ & $\begin{array}{c}\text { Coefficient of } \\
\text { Determination } \\
\qquad\left(R^{2}\right)\end{array}$ & $\begin{array}{l}\text { Mean Squared } \\
\text { Error } \\
\text { (MSE) }\end{array}$ & $\begin{array}{l}\text { Mean } \\
\text { Absolute } \\
\text { Error } \\
\text { (MAE) }\end{array}$ & $\begin{array}{l}\text { Sum of } \\
\text { Squared Errors } \\
\text { (SSE) }\end{array}$ \\
\hline \multirow{2}{*}{$\begin{array}{l}\text { Compressive } \\
\text { strength }\end{array}$} & 7 & 0.733934 & 0.278883 & 0.430889 & 4.183241 \\
\hline & 28 & 0.853518 & 0.288364 & 0.416 & 4.325458 \\
\hline \multirow{2}{*}{$\begin{array}{l}\text { Flexural } \\
\text { strength }\end{array}$} & 7 & 0.793707 & 0.013431 & 0.087035 & 0.201460 \\
\hline & 28 & 0.956548 & 0.007614 & 0.067962 & 0.114208 \\
\hline \multirow{2}{*}{$\begin{array}{l}\text { Split tensile } \\
\text { strength }\end{array}$} & 7 & 0.978643 & 0.002563 & 0.042321 & 0.038442 \\
\hline & 28 & 0.984468 & 0.013609 & 0.042755 & 0.040851 \\
\hline
\end{tabular}

Figure 6. Test errors of fibre reinforced concrete against hidden neurons

Table 2. Comparison between the $R^{2}, M S E, M A E$ and SSE for all specimens 

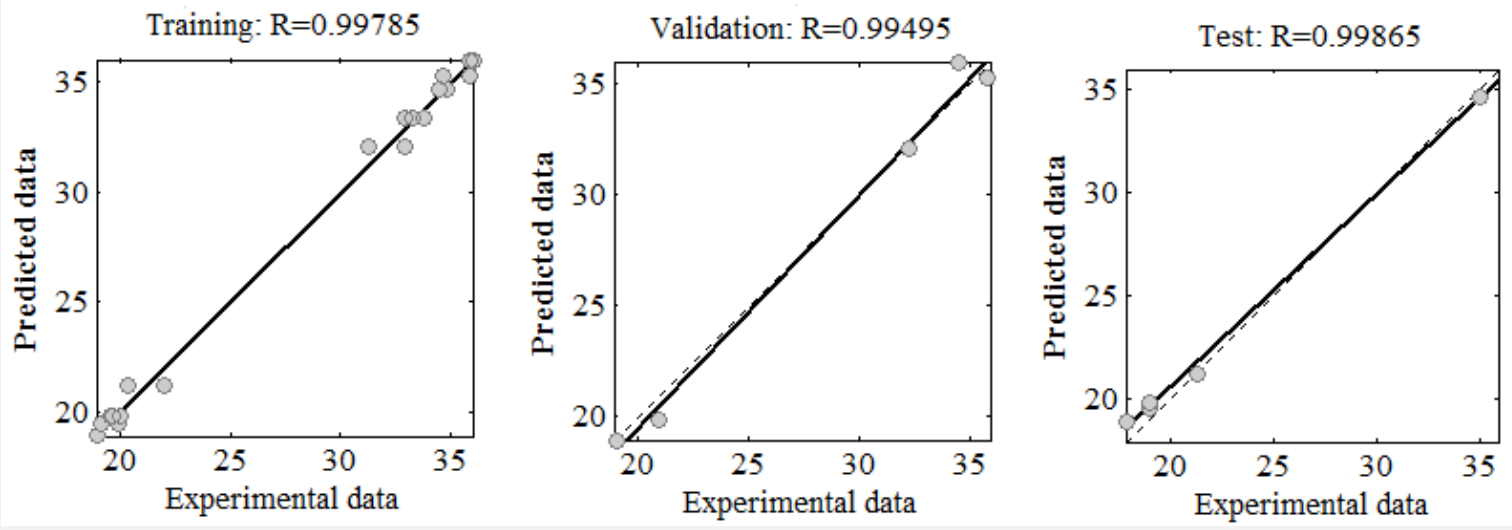

Figure 7. ANN graph for Compressive strength of the fibre reinforced concrete
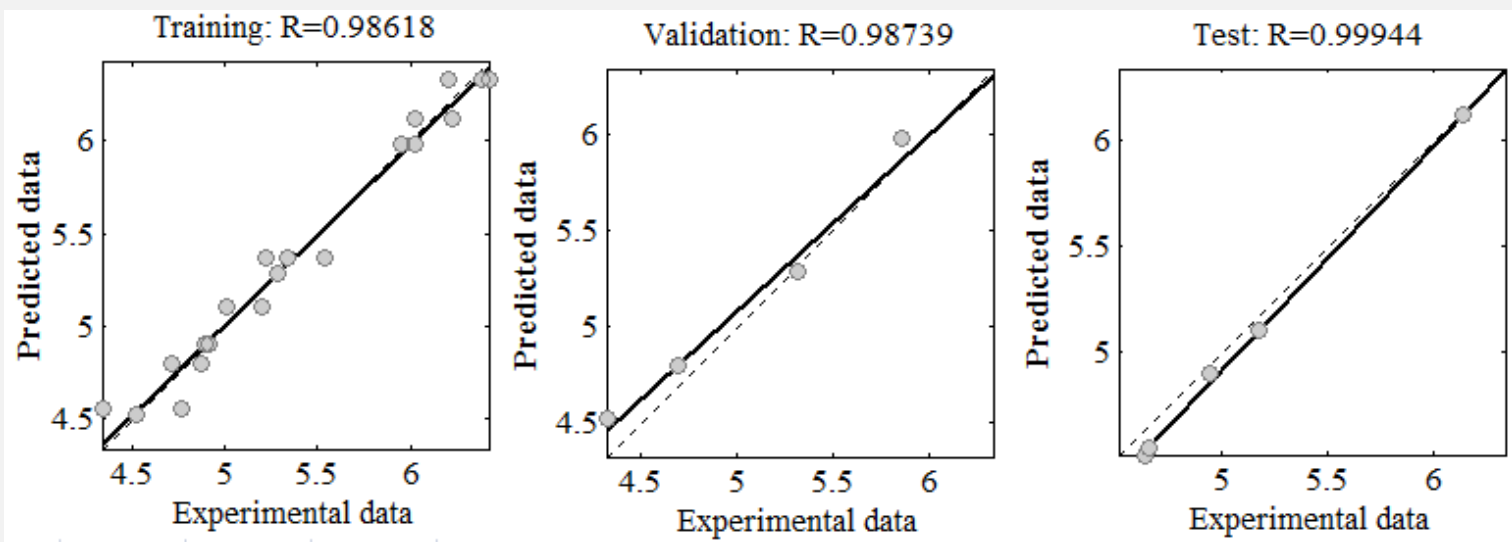

Figure 8. ANN graph for Flexural strength of the fibre reinforced concrete
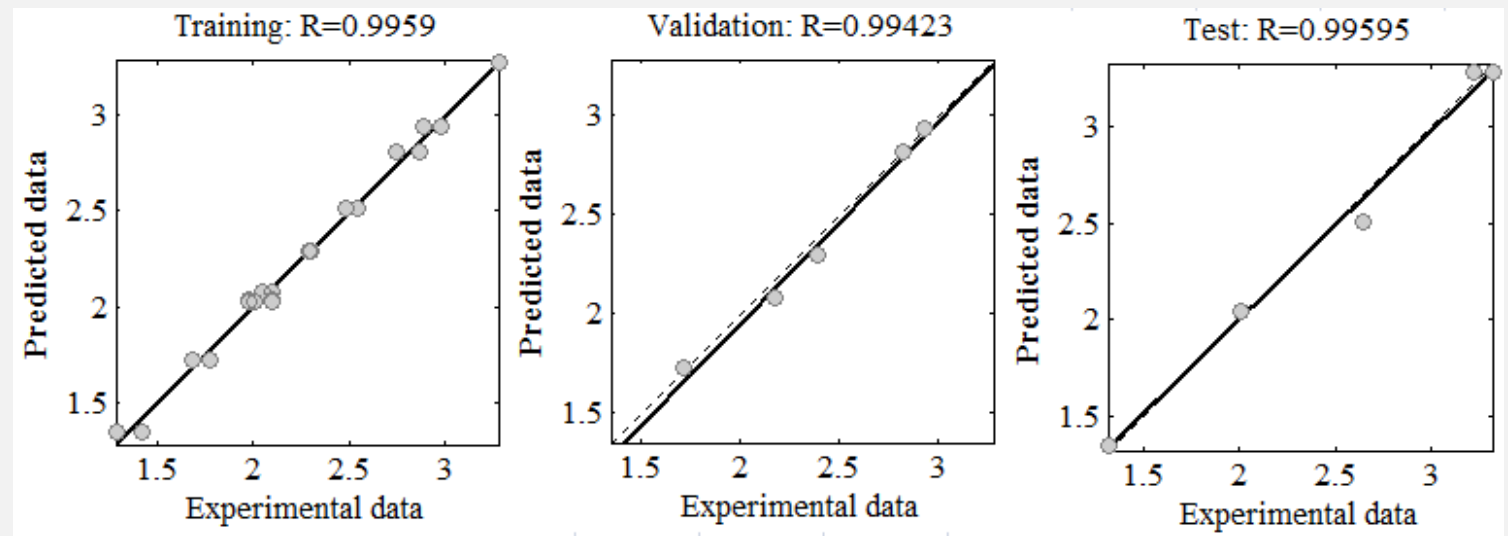

Figure 9. ANN graph for Split Tensile strength of the fibre reinforced concrete 
Figure 10 shows convergence characteristics of the ANN model during the training, validation and testing phases respectively and the Table 3 gives the comparison of the test conducted on the predicted models. In addition, it shows the number of epochs (4, $4 \& 6$ iterations) and the best validation performance, which is 0.71201 at 2 iterations, 0.01369 at 4 iterations and 0.00404 at 5 iterations for compressive strength, flexural strength and split tensile strength respectively.
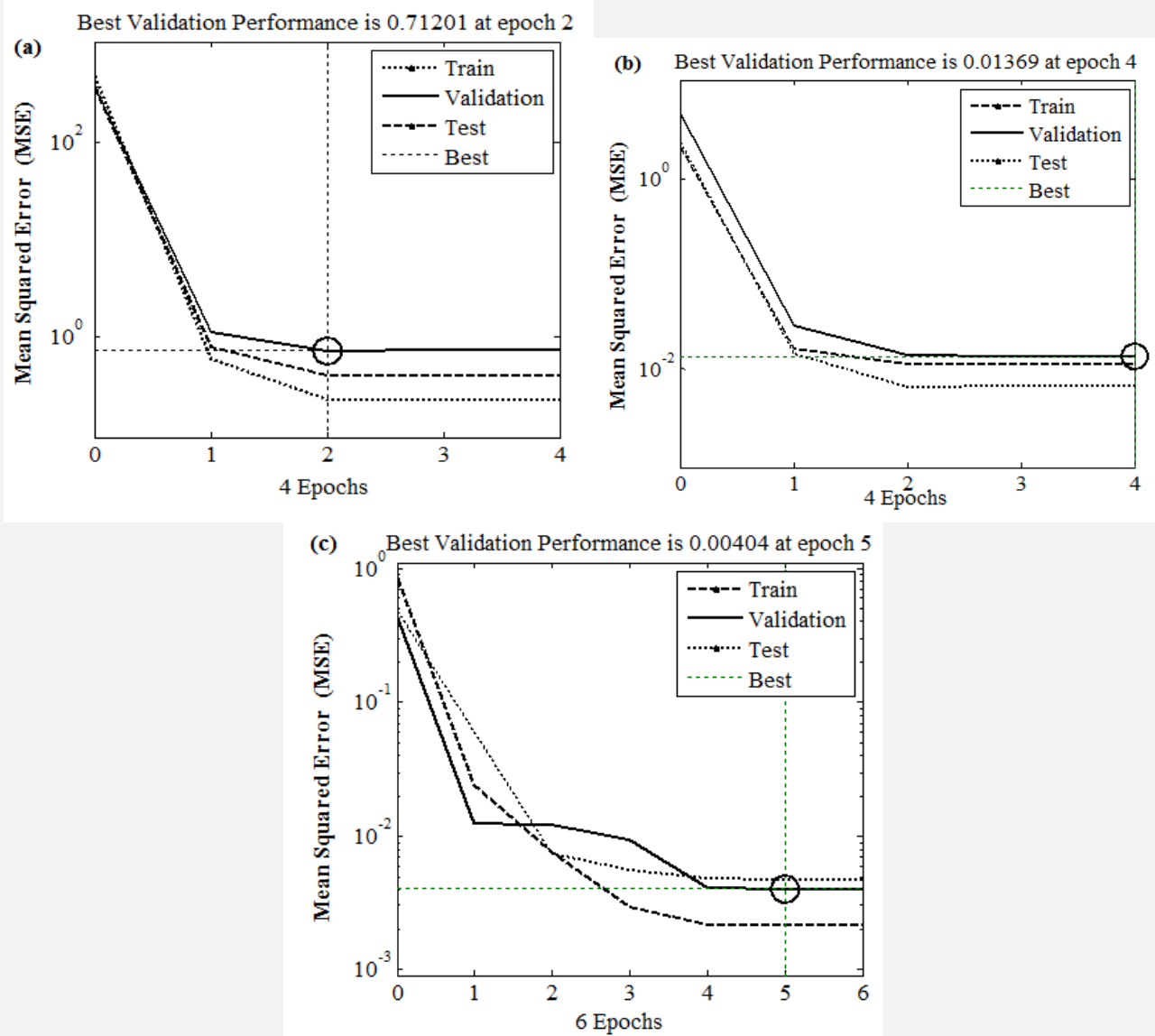

Figure 10. Performance plot for Polypropylene fibre Reinforced Concrete

Table 3. Comparison between the experimental and predicted strength of PFRC

\begin{tabular}{|c|c|c|c|c|c|c|c|c|c|}
\hline \multirow[b]{2}{*}{$\begin{array}{l}\% \text { of } \\
\text { Fibre }\end{array}$} & \multicolumn{3}{|c|}{ Compressive Strength (N/mm²) } & \multicolumn{3}{|c|}{$\begin{array}{c}\text { Flexural Strength } \\
\left(\mathrm{N} / \mathrm{mm}^{2}\right)\end{array}$} & \multicolumn{3}{|c|}{$\begin{array}{c}\text { Split Tensile Strength } \\
\left(\mathrm{N} / \mathrm{mm}^{2}\right)\end{array}$} \\
\hline & $\begin{array}{l}\text { Exp. } \\
\text { Value }\end{array}$ & $\begin{array}{l}\text { Predicted } \\
\text { Value }\end{array}$ & $\begin{array}{l}\text { Prediction } \\
\text { Error } \\
(\%)\end{array}$ & $\begin{array}{l}\text { Exp. } \\
\text { Value }\end{array}$ & $\begin{array}{l}\text { Predicted } \\
\text { Value }\end{array}$ & $\begin{array}{c}\text { Prediction } \\
\text { Error } \\
(\%) \\
\end{array}$ & $\begin{array}{l}\text { Exp. } \\
\text { Value }\end{array}$ & $\begin{array}{l}\text { Predicted } \\
\text { Value }\end{array}$ & $\begin{array}{l}\text { Prediction } \\
\text { Error } \\
(\%)\end{array}$ \\
\hline \multicolumn{10}{|c|}{7 days } \\
\hline 0 & 18.89 & 18.8917 & 0.0017 & 4.64 & 4.52 & -0.12 & 1.28 & 1.3500 & 0.0700 \\
\hline 0.5 & 19.11 & 19.4900 & 0.3800 & 4.77 & 4.555 & -0.215 & 1.77 & 1.7250 & -0.0450 \\
\hline 1 & 20 & 19.7788 & -0.2212 & 4.87 & 4.795 & -0.075 & 2.01 & 2.0400 & 0.0300 \\
\hline 1.5 & 21.33 & 21.2050 & -0.1250 & 4.89 & 4.905 & 0.015 & 2.05 & 2.0750 & 0.0250 \\
\hline 2 & 19.98 & 19.8312 & -0.1488 & 5.2 & 5.105 & -0.095 & 2.39 & 2.2950 & -0.0950 \\
\hline \multicolumn{10}{|c|}{28 days } \\
\hline 0 & 32.29 & 32.0901 & -0.1999 & 5.29 & 5.29 & 0.0000 & 1.98 & 2.0300 & 0.0500 \\
\hline 0.5 & 33.82 & 33.3179 & -0.5021 & 5.54 & 5.3667 & -0.1733 & 2.54 & 2.5100 & -0.0300 \\
\hline 1 & 34.8 & 34.6469 & -0.1531 & 5.95 & 5.985 & 0.035 & 2.87 & 2.8100 & -0.0600 \\
\hline 1.5 & 34.62 & 35.2519 & 0.6319 & 6.14 & 6.12 & -0.02 & 2.98 & 2.9350 & -0.0450 \\
\hline 2 & 36 & 35.9438 & -0.0562 & 6.42 & 6.3333 & -0.0867 & 3.22 & 3.2800 & 0.0600 \\
\hline
\end{tabular}




\section{CONCLUSIONS}

This study is aimed to find the best model to predict the compressive strength, flexural strength and split tensile strength at 7 days and 28 days curing using ANN. A total of 90 values were trained to predict the mechanical strength of polypropylene fibre Reinforced Concrete by 3 ANN models. All the outputs are compared using the coefficients of determination calculated for the highest $\mathrm{R}^{2}$ values. The following conclusions are obtained from the study.

- From the predicted results of mechanical properties of the polypropylene fibre reinforced concrete, it is concluded that ANN models are more suitable and accurate for prediction of 28 days strength based on the $\mathrm{R}^{2}$ values obtained from the ANN model.

- The Mean Squared Error (MSE) for all three models for predicting the compressive, split tensile and flexural strength are very low and nearly equal to zero. The correction coefficient $(R)$ for all three models are greater than 0.85 and it is acceptable.

- ANN model with $\mathrm{R}^{2}=0.9844, \mathrm{MSE}=0.0136$ and SSE $=0.03844$ are found to be capable of predicting the 28 days split tensile strength.

- The increase in the number of independent variables leads to the increase in the accuracy of the ANN model.

\section{REFERENCES}

[1] A.W.Otunyo\&A.J.Odebiyi, "Regression Modeling of the Strength Properties of Concrete Reinforced with Polypropylene Fibre and Alkali Resistant Glass Fibre", Nigerian Journal of Technology, vol. 37, no.4, (2018), pp.898-906.

[2] MeltemOzturan, BirgulKutlu\&TuranOzturan, "Comparison of concrete strength prediction techniques with artificial neural network approach", Building Research Journal, vol. 56, no.1, (2008), pp. $23-36$.

[3] Seung - Chang Lee, "Prediction of concrete strength using artificial neural network", Engineering Structures, vol. 25, (2003), pp.849 - 587.

[4] Ali Nazari \&ShadiRiahi, "Prediction of split tensile strength and water permeability of high strength concrete containing $\mathrm{TiO}_{2}$ nanoparticles by artificial neural network and genetic programming", Composites: Part B, vol. 42, (2011), pp.473-488.

[5] Lyes Bal \& Francois Buyle-Bodin, "Artificial neural network for predicting drying shrinkage of concrete", Construction and Building Materials, vol.38, (2013), pp.248-254.

[6] Sumathi A \& Saravana Raja Mohan, "Strength Predictions of Admixed High Performance Steel Fiber Concrete", International Journal of ChemTech Research, vol.6, no.11, (2014), pp.4729 - 4736.

[7] Sangeetha P \&Shanmugapriya M, "Numerical study on FRP wrapped concrete columns under compression", Indian Journal of Science and Technology, vol.12, no.15, (2019), pp. 1 - 7 .

[8] FaezehossadatKhademi,SayedMohammadmehdi Jamal, Neela Deshpande \&ShreenivasLondhe "Predicting strength of recycled aggragate using Artificial neural network, Adaptive neuro-fuzzy inference system and Multiple Linear Regression" International Journal of Sustainable Built Environment, vol. 5, (2016) ,pp. 355 - 369.

[9] Osama A. Hodhod, Mohamed S.Khalafalla\&MohanedS.M.Osman, "ANN models for nano silica/silica fume concrete strength prediction", Water Science, vol. 33, no. 1, (2019), pp.118-127.

[10] Palika Chopra, Rajendra Kumar Sharma \&Maneek Kumar "Prediction of compressive strength of concrete using artificial neural network and genetic programming", Advances in Materials Science and Engineering, vol. 2016, (2016), pp. 1-10. 


\section{PREDICTION OF MECHANICAL STRENGTH OF POLYPROPYLENE FIBRE REINFORCED CONCRETE USING ARTIFICIAL NEURAL NETWORK}

\section{P. SANGEETHA \\ M. SHANMUGAPRIYA}

The usefulness of fibre reinforced concrete (FRC) in various civil engineering applications is indisputable. Fibre reinforced concrete has been successfully used so far in construction of structures like bridges, industrial structures, concrete, architectural panels, precast products, offshore structures and many other applications. This paper presents the study on the mechanical properties of the polypropylene fibre reinforced concrete. The parameters varied in the study include volume of fibre $(0 \%, 0.5 \%, 1.0 \%, 1.5 \% \& 2.0 \%)$ and the curing period ( 7 days and 14 days). From the study it is concluded that the further increases in the volume of fibre reduces the water cement ratio. The mechanical properties of the polypropylene fibre reinforced concrete were also predicted by using Artificial Neural Network (ANN) and found to have minimal error when compared to actual experimental results.

Keywords: Polypropylene fibre, fibre content, curing period, strength prediction, ANN

\section{PREDVIĐANJE MEHANIČKE ČVRSTOĆE BETONA OJAČANOG POLIPROPILENSKIM VLAKNIMA KORIŠĆENJEM VEŠTAČKE NEURONSKE MREŽE}

\section{P. SANGEETHA \\ M. SHANMUGAPRIYA}

Upotrebljivost betona ojačanog vlaknima (FRC) $u$ različitim građevinarskim primenama je nesporna. Armirani beton ojačan vlaknima do sada se uspešno koristi u izgradnji objekata kao što su mostovi, industrijske konstrukcije-objekti, betonski arhitektonski paneli, gotovi proizvodi, morske konstrukcije i mnoge druge. U ovom radu je predstavljeno istraživanje mehaničkih svojstvima armiranog betona od polipropilenskih vlakana. Parametri koji su varirali u istraživanju uključuju zapreminu vlakana $(0 \%, 0,5 \%, 1,0 \%, 1,5 \%$ i $2,0 \%)$ i period očvršćavanja $(7$ dana i 14 dana). Iz analize istraživanja je zaključeno da dalje povećanje zapremine vlakana smanjuje odnos vodo - cementnog faktora. Mehanička svojstva betona ojačanog sa polipropilenskim vlakanima takođe su predviđena korišćenjem veštačke neuronske mreže (ANN) i utvrđeno je da imaju minimalnu grešku u poređenju sa stvarnim eksperimentalnim rezultatima.

Ključne reči: Polipropilenska vlakna, sadržaj vlakana, period očvršćavanja, predviđanje čvrstoće, ANN 